\title{
ODNALEZIENIE PRAWDZIWEGO KRZYŻA Syryjska legenda Judy Kyriaka \\ (Inventio verae Crucis: Syriaca legenda Judae Cyriaci)
}

\section{WSTEP}

Legenda o Judzie Kyriaku, żydzie nawróconym na chrześcijaństwo, to jedna $\mathrm{z}$ trzech wersji legendy o znalezieniu Krzyża Świętego. Dwie inne to legenda o Helenie i o Protonike; wszystkie trzy wersje pochodzą z przełomu IV/V wieku.

Treścią legendy o Judzie Kyriaku jest opowieść o przybyciu cesarzowej Heleny do Jerozolimy w poszukiwaniu Krzyża Jezusowego. Zgromadziła ona trzy tysiące żydów z miasta i z okolic, każąc im sprowadzić uczonych w Piśmie. Pięciuset uczonych stawiło się przed cesarzową, która zarzuciła im brak wiary w Jezusa Chrystusa i odesłała ich. Gdy zaskoczeni żydzi dyskutowali nad intencją Heleny, jeden z nich (Juda) wyraził swój domysł, że szuka ona drzewa Krzyża. Wyznał też, że ojciec nakazał mu wskazać miejsce ukrycia Krzyża, gdy będzie o to pytany. Wówczas żydzi wysłali go do cesarzowej; on jednak nie umiał wskazać miejsca, gdzie ukryte było drzewo Krzyża. Rozgniewana Helena kazała wrzucić Judę do wyschłej studni na siedem dni. Po tygodniu Juda zdecydował się pomóc cesarzowej: udał się na Golgotę i prosił Boga, by wskazał mu to miejsce. Bóg wysłuchał jego prośby i objawił mu, gdzie został ukryty Krzyż Chrystusa. Juda zaczął kopać i odkrył trzy krzyże; prawdziwy Krzyż rozpoznano po tym, że przywrócił życie osobie zmarłej. Helena zbudowała kościół w miejscu znalezienia Krzyża, a Juda przyjął chrzest i nawet został biskupem Jerozolimy. Jego nowe imię, Kyriakos, oznaczał przynależność do Pana Jezusa (Kú@ı૬). Na prośbę Heleny szukał on nadal, a Bóg wskazał mu gwoździe, którymi przebite były niegdyś dłonie Chrystusa. Gwoździ tych użyto do sporządzenia cugli dla konia cesarza Konstantyna, aby spełniło się proroctwo Zachariasza: „Owego dnia będzie, co na uździe końskiej jest, poświęcone Panu" $(14,20)$. Kiedy się to wszystko spełniło, cesarzowa kazała wypędzić żydów z Jerozolimy i z Judei, a dzień odnalezienia Krzyża świętować co roku.

W naszym przekładzie oprzemy się na syryjskim tekście legendy z rękopisu Petersburskiego (N.S. 4), który różni się znacznie od znanych dotychczas wersji 
tekstu. Najpierw jednak należy przypomnieć legendy o Helenie i o Protonike, a także historię badań nad wątkiem literackim inventio Crucis.

Legenda o cesarzowej Helenie to najstarsza wersja historii odkrycia Krzyża. Pierwszym chronologicznie świadectwem tej legendy jest mowa św. Ambrożego, wygłoszona w 395 r. na pogrzebie cesarza Teodozjusza Wielkiego ${ }^{1}$. Ponieważ jest to tekst łaciński, przyjął się pogląd o zachodnim pochodzeniu legendy. Dziś jednak wiadomo, że legenda ta powstała w poł. IV wieku w Jerozolimie (Heid, Borgehammar, Drijvers) ${ }^{2}$, a zapisał ją po grecku (ok. 390 r.) Gelazjusz, biskup Cezarei Palestyńskiej; jej przekład łaciński zachował się w Historii kościelnej Rufina z Akwilei ${ }^{3}$. Ten tekst pierwotny był szeroko wykorzystywany przez pisarzy chrześcijańskich Wschodu i Zachodu (Ambroży, Suplicjusz Sewer, Sokrates, Sozomen, Teodoret). W streszczeniu legenda o Helenie przedstawia się następująco: matka cesarza Konstantyna Wielkiego wybrała się do Jerozolimy w poszukiwaniu Krzyża. Pod odkryciu trzech krzyży, zidentyfikowano prawdziwy Krzyż Chrystusa z pomocą biskupa Makarego, dzięki cudowi uzdrowienia bądź wskrzeszenia. Na miejscu znalezienia Krzyża ufundowała Helena wspaniałą bazylikę Grobu Pańskiego. Część relikwii Krzyża przesłała synowi (wraz z relikwiami gwoździ), a część zostawiła w Jerozolimie.

$\mathrm{Na}$ początku $\mathrm{V}$ wieku rozwinęła się druga wersja legendy, związana $\mathrm{z}$ imieniem Protonike. Nie znają jej źródła greckie ani łacińskie, ale jedynie rękopisy syryjskie (a później armeńskie). Miejscem jej pochodzenia jest więc niewątpliwie północna Mezopotamia, zapewne miasto Edessa. Na pocz. V wieku, gdy biskupem Edessy był Rabbula (412-436), tradycje o znalezieniu Krzyża włączono w ostateczną redakcję Nauki Addaja. Mówi ona o przyjęciu chrześcijaństwa w królestwie Edessy za rządów Abgara V Ukkamy, bezpośrednio po śmierci Jezusa. Włączenie legendy o Krzyżu do Nauki Addaja, miało ukazać więź Kościoła Edessy nie tylko z Jerozolimą, ale także z Bizancjum i cesarstwem. Najstarszy tekst legendy o Protonike znajduje się w Petersburskim rękopisie Nauki Addaja, który opublikował Philips (1876).

Legenda o Protonike stanowi lokalną adaptację legendy o Helenie. Przynieśli ją do Edessy zapewne pielgrzymi wracający z Jerozolimy. Sam zresztą biskup Rabbula odwiedził Jerozolimę i musiał znać legendę o Krzyżu. Włączenie jej do Nauk Addaja spowodowało przesunięcie akcji na I wiek po Chrystusie. Helena, główna bohaterka legendy, musiała więc ustąpić miejsca fikcyjnej cesarzowej Protonike, rzekomej żonie Klaudiusza. Jej imię jest zupełnie nieznane w historii, ale ma znaczenie symboliczne: odnosi się do

${ }^{1}$ Por. De obitu Theodosii 40-49, PL 16, 1462-1466, tłum. J. Czuj, POK 21, 255-260.

2 Por. np. S. Heid, Der Ursprung der Helenalegende im Pilgerbetrieb Jerusalems, JACh 32 (1989) 41-71.

${ }^{3}$ Por. Rufinus, HE X 7-8. 
pierwszego zwycięstwa Krzyża, po jego pierwotnym odkryciu. Protonike nawróciła się w Rzymie za sprawą Szymona Piotra, a następnie udała się z dziećmi do Jerozolimy szukać Krzyża. Żydom, mającym nadzór nad Golgotą, nakazała oddać święte miejsca Jakubowi, który był pierwszym biskupem Jerozolimy. Następnie weszła do Grobu Pańskiego i odnalazła tam trzy krzyże. W tym samym czasie towarzysząca jej córka upadła martwa na ziemię. Cesarzowa Protonike, dotykając kolejno trzema krzyżami zwłok, zdołała rozpoznać Prawdziwy Krzyż, który przywrócił życie dziecku. Na koniec przekazała Prawdziwy Krzyż biskupowi Jakubowi, aby go strzegł z największą czcią, a nad miejscem ukrzyżowania i Grobu kazała zbudować kościół. Gdy Protonike wróciła do Rzymu i opowiedziała wszystko Klaudiuszowi, cesarz kazał wypędzić żydów z Italii.

Legenda o Judzie Kyriaku jest trzecią wersją podania, powstałą zapewne na początku V wieku. Podobnie jak Protonike, również tytułowy bohater tej legendy jest postacią fikcyjną; jego rola ma tu znaczenie symboliczne i przysłania postać cesarzowej Heleny. Zainteresowanie legendą o znalezieniu Krzyża wzrosło wśród badaczy końca XIX wieku. Poszukiwania były jednak utrudnione, ponieważ większość materiałów źródłowych nie była jeszcze opublikowana. W roku 1889 A. Holder wydał rękopis łaciński ${ }^{4}$, a E. Nestle jeden grecki (Sinai 493) i dwa syryjskie ${ }^{5}$. W dwa lata później K. Wotke opublikował kolejny rękopis grecki ${ }^{6}$, co dało podstawę do badań porównawczych. J. Straubinger (1912) doszedł do wniosku, że łacińskie inventio Crucis pochodzi od prototypu syryjskiego.

Współczesną dyskusję nad legendą pobudziła na nowo rozprawa E.D. Hunta (1982) o pielgrzymkach do Ziemi Świętej w okresie późnego cesarstwa. Zwrócił on uwagę na wzrost liczby pielgrzymów do Jerozolimy po wybudowaniu bazyliki Grobu Pańskiego na Golgocie i złożeniu tam relikwii Krzyża. Jego zdaniem legenda o Helenie wywodzi się z Jerozolimy i musiała być spisana w języku greckim, gdyż był to oficjalny język liturgii. Również S. Heid (1989) uważa, że legenda należy do liturgii jerozolimskiej i była czytana w święto Znalezienia Krzyża (13 września). S. Borgehammar (1991) i J.W. Drijvers (1992) uznają powiązanie między budową bazyliki Konstantyna na Golgocie a znalezieniem drzewa Krzyża. Borgehammar jednak twierdzi, że Helena faktycznie odnalazła Krzyż Chrystusa, podczas gdy Drijvers uważa to za fikcję literacką. Jego zdaniem, dopiero w 2. poł. IV wieku połączono fakt odnalezienia Krzyża z imieniem cesarzowej Heleny, a twórcą legendy był Cyryl, patriarcha Jerozolimy († 387).

\footnotetext{
${ }^{4}$ Por. Paris. BN 2769.
}

5 Por. Londin. BL Add. 12.174 datowany na r. 1196 i BL Add. 14.644 datowany na koniec V lub początek VI wieku.

${ }^{6}$ Por. Vat. Graec. 866. 
Istnieje powszechna zgodność w tym, że legenda o Helenie stanowi oryginalną wersję podania, na której bazują legendy o Protonike i o Kyriaku. M. Van Esbroeck (1979) dowodził jednak, że wszystkie trzy wersje legendy o znalezieniu Prawdziwego Krzyża powstały na przełomie IV i V wieku, kiedy to patriarcha Jerozolimy, Jan II (387-417), ustanowił urząd strażnika Krzyża

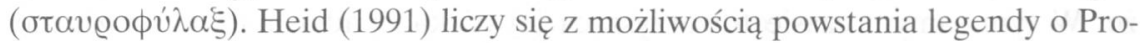
tonike w Jerozolimie, sam jednak wyraźnie optuje za jej pochodzeniem syryjskim w kontekście Nauk Addaja; podobnie twierdzą Borgehammar i Driver. Co do legendy o Kyriaku, jej syryjskie pochodzenie było do niedawna powszechnie uznawane; najnowsze badania jednak wskazują na Jerozolimę jako miejsce jej powstania.

Najstarsze rękopisy tej legendy datują się na przełom V/VI wieku i pochodzą z Syrii. Mimo to badacze dowodzą, że sama legenda powstała w Jerozolimie znacznie wcześniej. Terminus ante quem stanowi tu Historia kościelna Sozomena $^{7}$, wydana ok. 450 roku. Wynika z niej, że Helena znalazła drzewo Krzyża dzięki objawieniu Bożemu, a nie od „Hebrajczyka” szukającego w dawnych dokumentach. Sozomen zdaje się zatem znać ze słyszenia legendę o Kyriaku. Trudniej ustalić terminus post quem, ponieważ bazuje ona na legendzie o Helenie i musi być późniejsza od daty jej powstania (2. poł. IV wieku). Wzmianka o „pierwszym męczenniku” św. Szczepanie pozwala jednak bliżej określić tę datę: wiąże się ona $\mathrm{z}$ odkryciem jego relikwii w Kafargamala w grudniu 415 roku. Po tej dacie ,protomartyr” zostaje otoczony kultem i staje się wzorem dla postawy Kyriaka.

O ile wschodnie korzenie legendy o Kyriaku są oczywiste, to problem stanowi nadal język oryginału. Do niedawna panowała opinia, że musiał to być język syryjski, dziś natomiast część badaczy (Borgenhammar, Heid, Brock) skłania się ku greckiemu. Uwzględnienie wszystkich argumentów przemawia za pochodzeniem legendy z Jerozolimy, w konsekwencji czego językiem oryginalnym utworu byłaby greka: grecka wersja legendy dotarła do regionów języka syryjskiego i tam (zapewne w Edessie) została przetłumaczona w końcu IV wieku.

Legenda o męczeństwie Kyriaka łączy się ściśle z legendą o znalezieniu Krzyża. N. Pigulewska, która opublikowała rękopis Petersburski (N. S. 4) o Kyriaku, sądziła nawet, że obie legendy mają wspólnego autora i powstały w greckim środowisku Azji Mniejszej bądź Palestyny. Cechą szczególną tej legendy jest polemika z judaizmem. Helena oskarża żydów o ukrywanie Krzyża. Żydzi nie uwierzyli własnym prorokom i zaparli się Mesjasza. Złączyli się z szatanem, toteż Bóg ich opuścił. Apologetyczna legenda o Judzie Kyriaku należy więc, zdaniem Drijversa, do gatunku literatury propagującej chrześcijaństwo: znalezienie Krzyża przez Judę jest tu argumentem za mesjańską god-

${ }^{7}$ Por. Sozomenus, HE II 1, 4. 
nością Jezusa i oznacza ostateczną klęskę judaizmu. Antyżydowskie elementy w legendzie wpisują się idealnie w ówczesną polemikę traktatów Adversus Iudaeos.

Polemika nie jest jednak jedyną intencją autora legendy, który stara się nawrócić żydów. Są oni, w jego mniemaniu, potencjalnymi chrześcijanami, którzy w przeszłości nie odważyli się wyrazić swych przekonań z obawy przed sanhedrynem. Wynika to jasno z ukazania przodków Judy, którzy potajemnie wyznawali wiarę w Chrystusa. Juda doznał potęgi Boga chrześcijan i nawrócił się całym sercem, przyjmując chrzest. Następnie pełnił urząd biskupa Jerozolimy aż do męczeńskiej śmierci za panowania Juliana Apostaty (361-363). Sam dobór jego imion jest symboliczny: Juda (= Żyd) staje się Kyriakiem, tj. własnością Pana (Jezusa). Legenda jest więc wyrazem nadziei chrześcijan, że żydzi uznają kiedyś swój błąd i staną się wyznawcami Chrystusa.

$\mathrm{Na}$ koniec kilka uwag o rękopisach syryjskich tłumaczonej tu legendy. Średniowiecze zachodnie i bizantyjskie znało legendę o znalezieniu Krzyża w wersji łacińskiej, greckiej i syryjskiej. Najstarszy rękopis łaciński ${ }^{8}$ jest datowany na VI/VII wiek. Wersja grecka liczy osiem recenzji; najstarszy znany jej rękopis (Sinai 493) datuje się na przełom VIII i IX wieku. Spośród manuskryptów syryjskich, zawierających legendę o Kyriaku, cztery doczekały się publikacji i przekładu jeszcze w XIX wieku (Nestle i Bedjan). Najważniejszym z nich jest rękopis londyński ${ }^{9}$, z przełomu V/VI wieku.

Najnowsze wydanie krytyczne (H.J.W. i J.W. Drijvers) zawiera opracowanie i przekład dwóch innych manuskryptów, dotąd nie publikowanych. Jeden z nich to rękopis Petersburski (N. S. 4) z V wieku, a drugi, Synajski (Sparagma 40), datuje się na VI wiek. Ten drugi ma szczególne znaczenie dla tradycji manuskryptów syryjskich, wykazuje bowiem zgodność z najstarszym tekstem greckim, opublikowanym przez Nestlego (1895) a znalezionym także w bibliotece synajskiego konwentu (Sinai 493). Niestety, fragment syryjski zachował się tylko na osobnej karcie pergaminowej. Edycja Drijversów dołącza go w formie apendyksu do drukowanych synoptycznie dwu podstawowych kodeksów: Petersburskiego i Londyńskiego.

W naszym przekładzie wybieramy tekst Petersburski, zaznaczając jedynie w przypisach miejsca, w których różni się on od Londyńskiego BL Add. 14.644 (wydanego po raz pierwszy w pracy Nestlego z roku 1889). Choć bowiem oba rękopisy prezentują zasadniczo ten sam tekst, to różnią się w przekładzie oryginału greckiego tak bardzo, że niemożliwe było zastosowanie aparatu krytycznego.

\footnotetext{
8 Por. Paris. BN 2769.

9 Por. BL Add. 14.644.
} 


\section{WYDANIA TEKSTU}

P. Bedjan, Acta Martyrum et Sanctorum Syriace, t. 1, Paris 1890, 326-343.

H.J.W. Drijvers - J.W. Drijvers, The Finding of the True Cross. The Judas Kyriakos Legend in Syriac. Introduction, text and translation, CSCO 565, Subsidia 93, Louvain 1997.

A. Holder, Inventio Sanctae Crucis, Leipzig 1889.

E. Nestle, De Sancta Cruce, Berlin 1889.

E. Nestle, Die Kreuzauffindungslegende. Nach einer Handschrift vom Sinai, ByZ 4 (1895) 319-345.

N. Pigoulewsky, Le martyre de Saint Cyriaque de Jérusalem, ROC 26 (1927-1928) 305-349.

K. Wotke, Die griechische Vorlage der lateinischen Kreuzauffindungslegende, WS 12 (1891) 300-311.

\section{PRZEKŁADY NOWOŻYTNE}

Angielskie:

H.J.W. Drijvers - J.W. Drijvers, CSCO 565, 54-73.

Francuskie:

N. Pigoulewsky, ROC 26 (1927-1928) 305-349.

Niemieckie:

E. Nestle, ByZ 4 (1895) 319-349.

\section{BIBLIOGRAFIA}

J.B. Aufhauser, Konstantins Kreuzesvision in ausgewählten Texten, Bonn 1912; S. Borgehammar, How the Holy Cross was Found. From Event to Medieval Legend, Stockholm 1991; F.A. Consolino, Il significato dell'Inventio nel „De obitu Theodosii”, „Annali della Facoltà di Lettere e Filosofia” 5 (1984) 161-180; V.C. Corbo, Il Santo Sepolcro di Gerusalemme. Aspetti archeologici dalle origini al periodo crociate, Gerusalemme 1981-1982; H.A. Drake, Eusebius on the True Cross, JEH 36 (1985) 1-22; J.W. Drijvers, Helena Augusta. The Mother of Constantine the Great and her Finding of the True Cross, Leiden 1992; J.W. Drijvers, The Protonike legend and the „Doctrina Addai", StPatr 33 (1996) 517-523; S. Gibson - J.E. Taylor, Beneath the Church of the Holy Sepulchre Jerusalem. The Archaeology and Early History of Traditional Golgotha, London 1994; H. Gollancz, Julian the Apostate. Now translated for the first time from the Syriac original, Oxford 1928; S. Heid, Der Ursprung der Helenalegende im Pilgerbetrieb Jerusalems, JACh 32 (1989) 41-71; S. Heid, Zur frühen Protonikeund Kyriakoslegende, AnBol 109 (1991) 73-108; H. Heinen, Helena, Konstantin und die Überlieferung der Kreuzauffindung im 4. Jahrhundert, w: E. Aretz et al. (eds.), Der Heilige Rock zu Trier, Trier 1995, 83-117; E.D. Hunt, Holy Land Pilgrimage in 
the Later Roman Empire AD 312-460, Oxford 1982; G. Phillips, The „Doctrine of Addai", the Apostle. Now first edited in a complete Form in the Original Syriac, London 1876; V. Ryssel, Materialien zur Geschichte der Kreuzauffindungslegende in der syrischer Literatur, ZKG 15 (1895) 222-243; R.H. Storch, The Trophy and the Cross, „Byzantion” 40 (1970) 105-117; J. Straubinger, Die Kreuzauffindungslegende. Untersuchungen über ihre altchristlichen Fassungen mit besonderer Berücksichtigung der syrischen Texte, Paderborn 1912; M. Van Esbroeck, L'opuscule „Sur la Croix” d'Alexandre de Chypre et sa version géorgienne, „Bedi Kartlisa” 37 (1979) 102-132; M. Van Esbroeck, Jean II de Jérusalem et les cultes de S. Etienne, de la Sainte-Sion et de la Croix, AnBol 102 (1984) 99-134.

\section{PRZEKŁAD}

O tym, jak drzewo Krzyża znalezione w Jerozolimie powtórnie ${ }^{1}$ przez $^{2}$ świętą Helenę, matkę zwycięskiego Konstantyna, miłującego Boga władcy chrześcijańskiego.

1. Wizja Konstantyna ${ }^{3}$. W siódmym roku rządów cesarza Konstantyna Wielkiego, w miesiącu drugi Kanun ${ }^{4}$, liczne wojsko barbarzyńców ${ }^{5}$ zgromadziło się nad rzeką zwaną Danubis ${ }^{6}$ i chciało przeprawić się przez nią, aby zniszczyć wszystkie miasta, aż po Wschód. Kiedy cesarzowi Konstantynowi doniesiono, że oni się zgromadzili, natychmiast kazał zgromadzić także swoje wojsko u przejścia przez Dunaj. A po rozbiciu obozu nad brzegiem rzeki, nie pozwolił im się przeprawić. Czekali więc tam przez wiele dni. Kiedy już wielkie tłumy barbarzyńców były zgromadzone nad rzeką, zaczęli oni wszyscy nacierać na Konstantyna z wielką mocą. Widząc te wielkie tłumy, (cesarz) doznał wielkiego lęku i niepokoju. W ostatnią noc przez bitwą ujrzał on wyraźnie cudowne światło, które rozbłysło nad nim w kształcie krzyża, a litery ułożone przez gwiazdy oznajmiły mu: „w tym (znaku) zwyciężysz”. Kiedy obudził się i wstał, był bardzo poruszony i dowiadywał się starannie, od którego z bogów pocho-

* Przekładu dokonano z tekstu syryjskiego opracowanego przez H.J.W. Drijvers - J.W. Drijvers, CSCO 565, 36-53.

1 Ten szczegół miał znaczenie w tekście syryjskim, który zakłada znajomość legendy o Protonike. Ona bowiem odkryła Krzyż już w I wieku. Ponieważ jednak w czasie prześladowań za Trajana został on ponownie ukryty, jego znalezienie przez Judę w IV wieku było odkryciem powtórnym. Dodatku tego nie ma w wersji greckiej i łacińskiej.

2 Rkp Lond.: „w dniach (świętej królowej Heleny)”.

${ }^{3}$ Tytuły i numeracja paragrafów są moim dodatkiem (AT); cały ten fragment jest obecny tylko w rkp petersburskim.

${ }^{4}$ W kalendarzu syryjskim „drugi Kanun” odpowiada styczniowi.

${ }^{5}$ Syr. barbaria jest transkrypcją gr. $\beta \alpha \dot{\varrho} \beta \alpha \varrho o$ i oznacza ludy mówiące obcymi językami.

${ }^{6}$ Gr. nazwa Dunaju, będącego granicą imperium rzymskiego. 
dził ten znak (por. Mt 2,7). Kiedy już cały dwór ${ }^{7}$ zgromadził się na jego rozkaz, opowiedział im o swoim widzeniu. Bezzwłocznie też kazał sporządzić coś na kształt tego obrazu, jaki mu się ukazał, i rozkazał nieść to przed sobą podczas bitwy. Osiągnął wówczas wielkie zwycięstwo, wielu pobił, a innych wziął do niewoli.

Następnie, po kilku dniach, kazał przywołać kapłanów rzekomych bóstw. Pokazał im znak, który mu się objawił i zapytał ich: „Do którego z bóstw należy ten znak?” Odrzekli mu: „Nie jest to znak ziemskich bóstw, które czcimy, lecz potężny Znak Boga niebios. Kiedy bowiem ten znak przechodził, wszystkie bóstwa naszych świątyń padały i rozbijały się, a ich świątynie rozpadały się".

W tym samym czasie przyszli do cesarza chrześcijanie, których słudzy przedstawili mu jako Nazarejczyków ${ }^{8}$, i powiedzieli mu: „Panie, racz nas wysłuchać! To zwycięstwo, jakie zapowiedziano ci z nieba, (pochodzi) od Jezusa Chrystusa, Syna Bożego, żyjącego w wieczności. Kiedy On widział, że rodzaj ludzki ginie, nie wzgardził nim, lecz zstąpił jako jedyny Bóg, aby dać życie i odkupić swoje stworzenie. On to dobrowolnie podjął cierpienie i przez swe ukrzyżowanie sprowadził nas do Boga". Kiedy cesarz Konstantyn usłyszał te słowa, wysłał poselstwo do świętego Euzebiusza, biskupa Rzymu. A gdy już został przez niego pouczony i stał się prawdziwie wierzącym, wtedy przyjął chrzest wraz ze swą matką i wielką liczbą dworzan ${ }^{9}$. Następnie z wielką radością i mocą wyznanej wiary posłał swą matkę na Wschód, aby odszukała Krzyż Chrystusa i odbudowała Jerozolimę $e^{10}$.

2. Wyprawa Heleny. W roku $351^{11}$, za panowania miłującego Boga Konstantyna, święta i życiodajna łaska Ducha Świętego natchnęła wierną Helenę, matkę tegoż Konstantyna, godną tego wielkiego i wspaniałego daru. Była ona bowiem kobietą znającą wszystkie Pisma Święte i obdarzoną miłością do naszego Pana Jezusa Chrystusa. Trwając w takiej gorliwości, postanowiła ona wyruszyć na poszukiwania i odnaleźć Krzyż naszego Pana, Jezusa Chrystusa.

7 Syr. palatin, transkrypcja gr. $\pi \alpha \lambda \dot{\alpha} \theta \iota \mathrm{v}$, co oznacza pałac, ale także dworzan.

${ }^{8}$ Pierwotna nazwa chrześcijan (Dz 24, 5; 26, 9).

9 Widać tu podobieństwo do legendy o św. papieżu Sylwestrze, który przygotował Konstantyna do chrztu. Chociaż tamta legenda pochodzi z Rzymu, niektóre jej elementy były pochodzenia wschodniego, zwłaszcza opowiadanie o chrzcie cesarza.

${ }^{10}$ Czyniąc ją miastem chrześcijańskim. Po powstaniu Bar Kochby (135) Jerozolima stała się bowiem miastem pogańskim; na wzgórzu świątynnym stanęła świątynia Zeusa/Jupitera, a na Golgocie sanktuarium Afrodyty/Wenus. Dopiero Konstantyn zbudował na jej miejscu bazylikę Grobu Świętego (Eusebius, Vita Constantini III 26nn).

11 Możliwe, że autor bądź thumacz tekstu, pomylił datę odkrycia Krzyża z datą (351) pojawienia się błyszczącego Krzyża na niebie nad Golgotą. Wydarzenie to opisał Cyryl Jerozolimski w liście do Konstancjusza II, znanym również w przekładzie syryjskim. Teksty syryjskie, podobnie jak greckie i łacińskie, podają tu najróżniejsze daty, od 200 do 351 roku; por. List do cesarza Konstancjusza, thum. W. Kania, wstęp S. Longosz, VoxP 6 (1986) t. 10, 285-296. 
Odkąd dowiedziała się o wcieleniu naszego Pana i o tym, jak został powieszony na drzewie i zmartwychwstał trzeciego dnia ${ }^{12}$, postanowiła nie spocząć aż go odnajdzie. Wierząc w to mocno, udała się w podróż i przybyła do Jerozolimy, w przepychu i z licznym orszakiem, w 28 dniu miesiąca Ijar $^{13}$.

3. Spotkanie z żydami. Kazała zgromadzić mieszkańców miasta i okolicznych żydów. Mieli się zebrać nie tylko ci z miasta, lecz także ci, którzy mieszkali w (pozostałych) miașteczkach i wioskach. Jerozolima bowiem była wówczas niemal całkowicie spustoszona, a mieszkało w niej nie więcej niż trzy tysiące żydów ${ }^{14}$. Gdy się zgromadzili, cesarzowa rzekła do nich: „Czytałam w Piśmie Świętym, że byliście umiłowani przez Boga od najdawniejszych czasów. Ponieważ jednak odrzuciliście naukę Pisma i przeklęliście Tego, który chciał was uwolnić od przekleństwa Prawa (Ga 3,13), pluliście pogardą na Tego, który swoją śliną otworzył oczy ślepemu (Mk 8, 23-25; J 9, 6-7), ponieważ uznaliście Światło Prawdy za ciemność i kłamstwo - spadły na was wszystkie przekleństwa waszego Prawa (por. Pwt 28, 15-68). Zgromadźcie mi zatem spośród siebie ludzi mających dobrą znajomość Prawa, aby mogli mnie pouczyć we wszystkich sprawach, o które ich zapytam". Oni więc odeszli od niej z bojaźnią wielką i wyszukali wśród siebie tysiąc ludzi obeznanych z Prawem. Gdy ich zaś przyprowadzili do cesarzowej, ona zwróciła się do nich w słowach: „Słuchajcie mych słów i nakłońcie uszu na to, co powiem, nie rozumieliście bowiem słów dawnych proroków, którzy zapowiadali przyjście naszego Pana. Z tego powodu przybyłam, aby was przepytać. Otóż święty Dawid powiedział: „Zawsze stawiam sobie Pana przed oczy; On jest po mojej prawicy, abym się nie zachwiał" (Ps 16, 8; Dz 2, 25). Święty zaś Izajasz powiedział: „Synów wychowałem i wywyższyłem, a oni zgrzeszyli przeciwko Mnie. Wół rozpoznaje swego pana i osioł żłób swego właściciela, lecz mój lud mnie nie uznał, a Izrael mnie nie rozpoznał" (Iz 1, 2-3). Wszystkie również Pisma mówiły o Mesjaszu. Ponieważ byliście wykształceni w Prawie, poszukajcie mi jeszcze dziś ludzi, którzy są rzeczywiście dobrze obeznani z Prawem, abym mogła przepytać ich i otrzymać od nich odpowiedź". Święta Helena wydała następnie polecenie, aby żołnierze $^{15}$ ich strzegli i nie pozwolili im odejść, zanim nie dadzą odpowiedzi. Oni zaś naradzili się między sobą i wybrali spośród siebie około pięciuset ludzi. A gdy ci

${ }^{12}$ Podstawowa katecheza chrzcielna; por. Mt 27, 62; 28, 6; Mk 16, 6; Łk 24, 6-7.

13 W maju.

${ }^{14}$ Mowa tu o wyludnieniu Jerozolimy po stłumieniu powstania Bar Kochby (135). Cesarz Hadrian odbudował ją wówczas jako miasto pogańskie - Aelia Capitolina, podczas gdy Żydzi mieli tam zakaz wstępu (Eusebius, HE IV 6). Zakaz ten został jeszcze wzmocniony przez Konstantyna; tylko raz w roku Żydzi mogli pielgrzymować do Jerozolimy i opłakiwać zburzenie Świątyni (Itinerarium Burdigalense 591, 4). Por. też świadectwo Sokratesa Scholastyka (HE I 17): „[Helena] znalazła Jerozolimę pustą, jak mówi Prorok, niby szopa stróża ogrodu”.

${ }^{15}$ Dosł. „Rzymianie”, co jednak w syryjskim oznacza także żołnierzy. 
stawili się przed nią, zapytała ich: „Co to (za ludzie)?” Oni zaś odrzekli: „Ludzie, którzy doskonale znają Prawo”. Wtedy zaczęła ich pouczać na podstawie Pisma, mówiąc: „Zaiste nierozumni jesteście, synowie Izraela, jak mówi Pismo (por. Ps 14,1;53,1), bo postępujecie w ślepocie waszych przodków, tych morderców, którzy twierdzili, że Chrystus nie jest Bogiem. Czytacie Prawo i Proroków, ale nie rozumiecie”. Oni odrzekli: „Czytamy i rozumiemy. Co znaczą twoje słowa skierowane do nas, o Pani?" Mów do nas jaśniej i daj nam poznać, abyśmy również mogli odpowiedzieć twemu majestatowi według naszych możliwości”. Odrzekła im: „Idźcie i wybierzcie ludzi, którzy są najlepszymi znawcami Prawa”. Po odejściu mówili oni między sobą: „Dlaczego cesarzowa nałożyła na nas tak wielkie zadanie?"

4. Legenda o Judzie Kyriaku. Jeden z nich, imieniem Juda, rzekł do nich: „Domyślam się, że chce ona dowiedzieć się od nas o tym drzewie, na którym nasi ojcowie ukrzyżowali Jezusa. Ale jeśli nawet ktoś z nas wiedziałby o tym, nie może tego wyjawić. Gdyby to uczynił, przestałyby istnieć wszystkie święta naszych ojców, a Prawo zostałoby zniesione (por. Dz 18, 13). Zacheusz, mój dziad, przykazał umierając ojcu memu, a z kolei mój ojciec przed śmiercią przykazał mnie, mówiąc: «Synu mój, wiedz o tym, że szuka się drzewa, na którym nasi ojcowie powiesili Jezusa. Jeśli zdarzy się, że ludzie szukający go zapytają: gdzie ono jest, powiedz im, zanim zostaniesz zmuszony. Bowiem naród żydowski nie będzie już miał króla, lecz odtąd zwycięstwo będzie udziałem czcicieli Chrystusa i On będzie królował na wieki wieków. On bowiem jest Królem, Synem Boga żyjącego". A ja rzekłem do niego: Ojcze, skoro nasi przodkowie wiedzieli, że On jest Mesjaszem, czemu podnieśli na Niego ręce? On zaś tak mi odpowiedział: Posłuchaj mnie, mój synu! Jak mówili nasi ojcowie, nigdy nie byli oni sprzymierzeńcami krzyżujących; nawet sprzeciwiali się starszyźnie ludu i jego skrybom. Lud bowiem wiedział, że On był Mesjaszem. Ale tamtych Jezus ustawicznie napominał; oni więc z zawiści oskarżyli Go przed sądem i zabili, ponieważ sądzili, że On już nie wróci do życia, złożyli Go w grobie. On jednak trzeciego dnia zmartwychwstał i ukazał się swoim uczniom (por. Łk 24; J 20-21; Mk 16; Mt 28). Dlatego też uwierzył Szczepan, brat mego dziadka ${ }^{16}$, i zaczął nauczać w imię Jezusa. A faryzeusze i saduceusze zebrali się przeciwko niemu i ukamienowali go (por. Dz 6-7). W chwili konania modlił się on słowami: „Panie, nie poczytaj im tego grzechu i przyjmij ducha mego" (Dz 7, 60). Posłuchaj mnie teraz, mój synu, a ja cię pouczę o Jezusie. Również Szaweł, który był po stronie Świątyni i zajmował się wyrobem namiotów, prześladował Jezusa i wszystkich, którzy w Niego uwierzyli. On także uczestniczył w wielkim zgromadzeniu przeciwko naszemu bratu Szczepanowi, gdy był on kamienowany. A jednak Chrystus

${ }^{16}$ W różnych rękopisach pokrewieństwo Judy ze Szczepanem jest przedstawiane odmiennie; w każdym razie „pierwszy świadek” jest tu ukazany jako przodek Judy. 
okazał mu łaskę i uczynił go swoim uczniem (por. Dz 9, 1-9). Toteż, synu mój, tak jak przykazali mi ojcowie, prawdziwie wierzę, że On jest Synem Bożym. Również ty, synu, nie bluźnij Mu i nie pogardzaj tymi, którzy uwierzyli w Niego, a będziesz miał życie wieczne. Jeśli teraz, synu mój, za twoich dni szukać będą Krzyża, wskaż go, a jeśli nie - przekaż swoim synom to, co powiedziałem. Mój ojciec Szymon nakazał to mnie, a teraz ty to słyszysz ode mnie. Jak myślicie? Jeśli ona zapyta nas ponownie, jaką odpowiedź winniśmy jej dać w sprawie drzewa Krzyża”? Oni zaś odrzekli Judzie: „Nikt nam nigdy nie mówił o tym, co dziś usłyszeliśmy od ciebie. Teraz więc tak ci radzimy: skoro to drzewo Krzyża jest poszukiwane, to czemu nie miałbyś go wskazać, jeśli potrafisz? Bo przecież sam twierdzisz, że wiesz, gdzie ono jest". A gdy oni jeszcze rozprawiali o tym, przybyli do nich ponownie żołnierze z wieścią: „Cesarzowa was prosi”. Kiedy przybyli, rozprawiała $z$ nimi o wielu sprawach, lecz oni nie umieli jej odpowiedzieć. Kazała więc wydać ich na spalenie. Ponieważ zaś byli wystraszeni, wydali jej Judę, mówiąc: „Ten człowiek jest sprawiedliwym i najbardziej biegłym w Prawie; on ci wyjaśni wszystko, o co go zapytasz". Kiedy więc usłyszała to świadectwo, jakie wydali oni o Judzie, odesłała ich wszystkich, a zatrzymała tylko Judę. Rzekła do niego: „Gdyby dano ci do wyboru pomiędzy dobrym i spokojnym życiem, a śmiercią w strasznych męczarniach, co byś wybrał?” Juda odparł: „Któż chciałby na pustyni gryźć kamienie, jeśli może spożywać chleb?” (por. Mt 7, 9). Cesarzowa rzekła: „Jeśli chcesz wieść szczęśliwe życie w niebie i na ziemi, powiedz mi, gdzie można znaleźć drzewo Krzyża, i pokaż mi, gdzie jest ono ukryte!” Juda odrzekł: „Jak powiedziano w dokumentach?”17. Powiedziała cesarzowa: „Pokaż mi je!” Juda odparł: „Minęło już wiele lat od tamtego czasu, jakieś dwieście do trzystu lat. Czyż byliśmy wtedy choćby dziećmi? Skąd możemy znać te rzeczy?”. A ona wtedy odparła: „A cóż (powiedzieć) o tej wojnie sprzed wielu lat, o wojnie pod Troją czyli Ilionem? A przecież każdy nadal pamięta o niej, a ludzie tam żyjący potrafią wskazać jego grób!”18. Juda odrzekł: „To oczywiste, ponieważ wiemy o tym z pisanych dokumentów; my jednak takich nie mamy!” Cesarzowa odrzekła: „Często się zdarza, że nawet ludzie niewykształceni ${ }^{19}$ są obznajomieni z wielkimi sprawami. Przecież przed chwilą powiedziałeś mi, że to również jest (zapisane) w dokumentach!” Juda odparł: „Powiedziałem to, o Pani, tylko jako przypuszczenie”. Wtedy ona rzekła: „A ja wiem z Ewangelii ${ }^{20}$, że On został ukrzyżowany

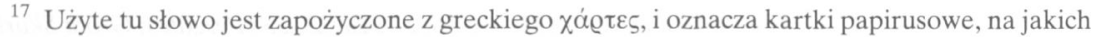
spisywano Ewangelie. Zwoje Tory były pergaminowe.

${ }^{18}$ Chodzi o Iliadę; wspomniany grób może być grobem Iliosa, mitycznego założyciela Ilionu. Autor legendy zdaje się nawiązywać do imienia Heleny, które wiąże się z akcją Iliady.

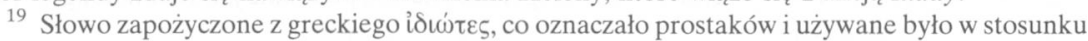
do chrześcijan (Dz 4, 13; 2Kor 11, 6).

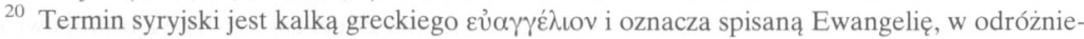
niu od ustnego kerygmatu (syr. karozuta'). 
na miejscu zwanym Golgota ${ }^{21}$. Wskaż mi tylko to miejsce, a ja go (Krzyż) odkryję (por. J 20, 15). Mam nadzieję, że odnajdę go, i moje pragnienie się spełni!” Juda odparł: „Ja również nie znam tego miejsca, o Pani, ponieważ wówczas nawet nasi ojcowie jeszcze się nie urodzili!". Cesarzowa odrzekła: „Przysięgam na Chrystusa, który został ukrzyżowany, że będę cię dręczyć głodem i pragnieniem, aż powiesz mi prawdę!" I natychmiast rozkazała wrzucić go do wyschłej studni na siedem dni. Po siedmiu dniach Juda z płaczem zawołał z wnętrza studni: „Proszę cię, wypuść mnie z tej studni, a ja ci wskażę miejsce, gdzie ukryte jest drzewo Krzyża!” A gdy wyszedł ze studni, udał się prosto na to miejsce, choć nie wiedział dokładnie, gdzie to było. I zawołał głośno po hebrajsku $^{22}$ : „Boże, Ty stworzyłeś niebo i ziemię i morze i wszystko, co w nich się znajduje; Ty zasiadasz na rydwanie cherubów latających w powietrzu (por Ez 1,1nn); Ty mieszkasz we wspaniałej światłości, której nic nie dorówna. Panie, Ty jesteś jedynym, który stworzył na swoją służbę niezliczonych serafinów, którzy ustawicznie wznoszą głos wołając: „Święty, święty, święty Pan Wszechmogący, którego chwała wypełnia niebo i ziemię" (Iz 6, 2-3); Ty jesteś Panem wszechświata, bo Twoje ręce uczyniły nas wszystkich. A teraz, Panie, jeśli Twoim życzeniem jest, aby królował syn Maryi, którego istnienie pochodzi od Ciebie [...]. Bo gdyby Jego istnienie nie pochodziło od Ciebie, nie mógłby On dokonać tych wielkich rzeczy i nie mógłby powstać z martwych. Teraz więc proszę Cię, Panie, dokonaj i tego cudu: tak jak wysłuchałeś Mojżesza i wskazałeś mu kości Józefa (por. Wj 13,19), tak i mnie wskaż to miejsce, gdzie zakopany został Jego Krzyż. Niech uniesie się od niego słodki zapach najprzedniejszych kadzideł, abym ja także mógł uwierzyć, że ukrzyżowany Chrystus jest Królem na wieki wieków”. A gdy zakończył on swoją modlitwę, natychmiast powstał wielki wstrząs na tym miejscu i rozszedł się stamtąd silny zapach kadzideł na wszystkie strony, a wszyscy się zdumiewali. Wtedy Juda złożył wyznanie: „Prawdzie, Tyś jest Chrystus, Zbawiciel światów ${ }^{23}$. Uwielbiam Cię, Panie, ponieważ nie pozbawiłeś mnie swej łaski, chociaż na to nie zasłużyłem. Proszę Cię, Panie Jezu, nie poczytuj mi moich grzechów, lecz wprowadź mnie do mego brata, Szczepana, który tryumfuje wraz z dwunastoma Apostołami”. A kiedy to powiedział, przepasał swe biodra i mężnie ujął oskard w ręce. Gdy przekopał około dwudziestu łokci ${ }^{24}$, znalazł trzy ukryte krzyże; wydobył je i przyniósł cesarzowej do miasta. A ona spytała go: „Powiedz mi, na którym z nich został ukrzyżowany Chrystus.

21 Dosł. „czaszka” (qarqafta); por. Mt 27, 33; Mk 15, 22 i Łk 23, 33 (Peszitta); Grota Skarbów XXIII 18

${ }^{22}$ Różne wersje legendy, wśród nich najstarsze rękopisy greckie i łacińskie zawierają zniekształcony tekst tej modlitwy. R. Harris (1894) sugerował nawet, podobnie jak J. Straubinger (1912), ze jest to tekst magiczny.

${ }^{23}$ Widzialnego i niewidzialnego, por. podobne wyznanie Samarytan: J 4, 42

${ }^{24}$ Legenda o Protonike dodaje, że za rządów Trajana Żydzi zabrali Krzyż biskupowi Jerozolimy i zakopali go na głębokości 20 łokci. 
Wiadomo mi bowiem, że dwa z nich to (krzyże) złoczyńców, którzy byli wraz z Nim ukrzyżowani" (por. Mt 27, 38 par). On zaś wystawił je pośrodku miasta i oczekiwali, aby ujrzeć chwałę Boga. Gdy zaś nadeszła godzina dziewiąta ${ }^{25}$, przenoszono tamtędy na marach zwłoki człowieka. Juda skupił się i powiedział do cesarzowej: „Teraz, o Pani, dowiemy się, który jest prawdziwie Krzyżem naszego Pana". Powiedziawszy to, Juda wziął mary i umieścił je przed cesarzową. Następnie położył (kolejno) dwa krzyże na zmarłym, ten jednak nie powsta $^{26}$. Dopiero gdy położył trzeci, na którym nasz Pan został ukrzyżowany, natychmiast zmarły powstał ${ }^{27}$. A wszyscy stojący tam ludzie zawołali głośno, wielbiąc Boga.

5. Zdemaskowanie Szatana. Wtedy Szatan, zazdrosny zawsze o piękne (sprawy), wszedł w pewnego człowieka. Ten zaczął wołać na cały głos, mówiąc: „Kim jest ten, kto nie chce oddać mi dusz? Jezusie Nazarejczyku, który pociągnąłeś cały świat ku sobie (por. J 12, 32), dlaczego objawiłeś swój Krzyż Judzie, który stanie się moim wrogiem? O, Judo, czemuś mi to uczynił? Poprzez pierwszego Judę dokonałem zdrady i zniewoliłem cały świat do grzechu ${ }^{28}$. Teraz jednak przez ciebie, Judo, doznaję udręki. Wiem już, co uczynię przeciw tobie: oto pójdę do przyszłego cesarza, który będzie chciał zniszczyć imię Ukrzyżowanego. On podda cię wielkim torturom, abyś się zaparł Tego, którego teraz wyznajesz!" 29 Juda rozgniewał się i stawił opór temu demonowi, mówiąc: „Niech cię napomni Chrystus, który swym słowem przywrócił zmarłemu życie" ${ }^{30}$. W ten samej chwili człowiek ów został uwolniony od demona. Cesarzowa zdumiewała się wiarą Judy, który uwielbił Boga. Wzięła czcigodny Krzyż z wielką troską, oprawiła go w czyste złoto i jeszcze (ozdobiła) klejnotami i perłami. Potem sporządziła wielką srebrną skrzynię i tam go umieściła ${ }^{31}$. Zbudowała też na tym miejscu, zwanym Golgotą ${ }^{32}$ wielki kościół. Juda zaś

${ }^{25}$ Trzecia po południu; być może aluzja do godziny skonania Jezusa: Mt 27, 46nn i par.

${ }^{26}$ Por. Łk 7,11-15 (młodzieniec z Nain).

${ }^{27}$ W starszej legendzie o Helenie (Ambrosius, De obitu Theodosii 45; por. Joannes Chrysostomus, In Joannem hom. 85) rozpoznanie prawdziwego Krzyża było możliwe dzięki napisowi (titulus), jaki na nim umieścił Piłat. Późniejsze wersje tejże legendy mówią o uzdrowieniu chorej kobiety (Rufinus, HE X 7; Socrates, HE I 17; Sozomenus, HE II 1; Theodoretus, HE I 18) albo wskrzeszeniu zmarłego (Paulinus, Epistulae 31, 5; Sulpicius Severus, Chronica II 34). Legenda o Protonike mówi o wskrzeszeniu córki cesarzowej.

${ }^{28}$ Zdrada Judasza Iskarioty: Mt 26, 14-16. 47-50 par.

29 Zapowiedź męczeństwa Judy za panowania Juliana Apostaty.

${ }^{30}$ Por. J 11, 38-44 (wskrzeszenie Łazarza).

${ }^{31}$ Egeria, która zwiedzała Jerozolimę w latach 381-384, wspomina, że Krzyż przechowywano w specjalnym relikwiarzu, por. Itinerarium Egeriae 37, 1: „loculus argenteus deauratus, in quo est signum sanctum crucis". O tym samym relikwiarzu mówi też legenda Heleny (Rufinus, HE X 8; Socrates, HE I 17; Theodoretus, HE I 18).

${ }^{32}$ Syr. Qarqafta. Wszystkie wersje legendy łączą odnalezienie Krzyża z budową Kościoła Grobu Pańskiego na Golgocie (por. Eusebius, Vita Constantini III 34-39). W rzeczywistości to 
wkrótce przyjął chrzest życia, gdy został utwierdzony w wierze, iż Chrystus jest Synem Bożym, ponieważ Bóg dokonał licznych znaków przez niego dzięki

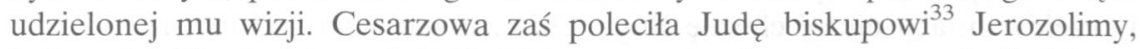
który udzielił mu chrztu. A kiedy biskup ten umarł, cesarzowa poleciła błogosławionemu biskupowi Euzebiuszowi ${ }^{34}$ i (innym) biskupom, którzy przy niej byli, aby włożyli na niego [Judę] ręce, ustanawiając go biskupem w Jerozolimie. Zmieniła mu też imię i nazwała go Kyriakiem ${ }^{35}$.

6. Odnalezienie świętych gwoździ. Z powodu swej wiary w naszego Pana, podjęła się też starannych poszukiwań tych gwoździ, którymi były przebite ręce naszego Pana. Powiedziała do błogosławionego Judy zwanego Kyriakiem: „Nie ustanę, a serce moje nie zazna spokoju, aż spełni się moje pragnienie przez Chrystusa, w którego wierzę. Ty również módl się do naszego Pana, a ja wierzę, że On ci (je) wskaże".

Tenże błogosławiony udał się ponownie z licznymi braćmi na miejsce, gdzie odnaleziono Krzyż. Wzniósł oczy ku niebu i bijąc się w piersi mówił: „Dziękuję $\mathrm{Ci}$, mój Panie, że uwolniłeś mnie z niewiedzy żydów. Oto sławię tych wszystkich, którzy już uwierzyli w Ciebie, a także tych, którzy dopiero mają uwierzyć w Ciebie” (por. J 17,20 ). I modlił się przez dłuższy czas oczekując, że ujrzy znak podobnie jak poprzednio. Gdy zaś zakończył swoją modlitwę i wyrzekł „amen”, ponownie zjawił się wielki znak, który ujrzeliśmy wszyscy. Potężny bowiem i silny strumień światła z nieba oświetlił to miejsce, przewyższając światło słoneczne, i ukazały się owe gwoździe jak błyszczące czyste złoto. Pojawiły się one w ziemi, a wszyscy, którzy (je) widzieli, uwierzyli mówiąc: „Prawdziwie Ten, który został ukrzyżowany, to nasz Pan, Jezus, Syn Boży” (por. Mt 27, 54 par). Błogosławiony Kyriak wziął je z szacunkiem i zaniósł cesarzowej Helenie. Ona zaś na ich widok uklękła, sławiąc i wielbiąc Chrystusa.

I rozważała, co można by z nich wykonać. Wtedy łaska Ducha Świętego podsunęła jej myśl wykonania z nich czegoś, co byłoby dobrym świadectwem dla przyszłych pokoleń. To, co niegdyś zapowiadał prorok, ona zapragnęła wykonać. Posłała więc po człowieka, który był zręcznym i mądrym rzemieślnikiem, i powiedziała mu: „Strzeż nakazu cesarskiego i tajemnicę cesarską wypełnij (por. Tb 12,7). Weź te gwoździe i wykonaj z nich cugle dla cesarskiego konia tak, aby stanowiły one broń przeciwko wszystkim wrogom [cesarza]. Teraz bowiem zwycięstwo należy do cesarza, a on pragnie pokoju w miejsce

nie Helena, lecz jej syn nakazał tę budowę, zapewne w r. 325, jak wynika to z listu cesarza do Makarego, biskupa Jerozolimy (Vita Constantini III 30-32).

33 Legenda o Helenie dodaje imię biskupa: Makarios.

${ }^{34}$ Mógł to być Euzebiusz z Cezarei, ówczesny metropolita Palestyny. Przypuszczalnie jednak mowa tu o Euzebiuszu ,z Rzymu” (tak w rkp Londin. Add. 14.644), który wraz z innymi biskupami towarzyszył Helenie w wyprawie do Jerozolimy.

35 Por. Wstęp. 
wojny. Tak miało się spełnić to, co powiedział Zachariasz: „Owego dnia będzie,

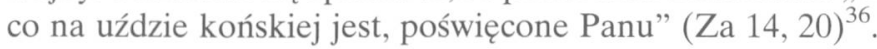

Po tym wszystkim błogosławiona Helena propagowała w Jerozolimie wiarę w naszego Pana. A gdy już dokonała tych wszystkich rzeczy, wznieciła prześladowanie żydów rozkazując, aby ich wszystkich usunąć z Jerozolimy i z całej Judei ${ }^{37}$.

7. Zakończenie. Bóg udzielił też łaski błogosławionemu Kyriakowi tak, iż wypędzał on swą modlitwą zastępy demonów i leczył wszelkie choroby. Błogosławiona Helena zaś ofiarowała liczne dary dla Jerozolimy i ustanowiła im biskupa dla podtrzymania ubogich ${ }^{38}$. Nakazała też, aby wszyscy, którzy uwierzyli i będą wierzyć, mężczyźni i kobiety, obchodzili wspomnienie dnia odnalezienia Krzyża każdego roku, na zawsze ${ }^{39}$. Ci zaś wszyscy, którzy wspominają Krzyż, będą mieli udział z błogosławioną Maryją, matką Chrystusa ${ }^{40}$, na wieki wieków. Amen.

[Kolofon]. Kończy się pismo o tym, jak drzewo Krzyża zostało odnalezione powtórnie w Jerozolimie przez cesarzową Helenę, matkę błogosławionego Konstantyna.

\author{
Z języka syryjskiego przełożył, \\ wstępem i komentarzem opatrzył \\ ks. Antoni Tronina - Lublin, KUL
}

${ }^{36}$ Połączenie odnalezienia świętych gwoździ z proroctwem Zachariasza jest znane w różnych wersjach legendy, por. Sozomenus, HE II 1, 9; Theodoretus, HE I 18; Ambrosius, De obitu Theodosii 47-48. Dla Ambrożego odnalezienie gwoździ było nawet ważniejsze, niż znalezienie drzewa Krzyża. Ich umieszczenie w hełmie cesarza i w cuglach jego konia wypełniało bowiem słowa proroctwa, a zatem ustanawiało cesarstwo chrześcijańskie. Hełm i cugle cesarz przekazywał swemu następcy, gwarantując tym sposobem tożsamość wiary chrześcijańskiej (hereditas fidei).

${ }^{37}$ Także legenda o Protonike kończy się wzmianką o wygnaniu Żydów z Italii przez cesarza Klaudiusza.

${ }^{38}$ Wzmianki o dziełach miłosierdzia Heleny potwierdzają historycy Kościoła (Socrates, HE I 17; Sozomenus, HE II 2). Ten element legendy o Helenie sięga zapewne dzieła Euzebiusza (Vita Constantini III 44-45).

${ }^{39}$ Katechezy Cyryla Jerozolimskiego $(4,10 ; 10,19 ; 13,4)$ potwierdzają, że w połowie IV wieku Krzyż Chrystusa był czczony w jerozolimskiej bazylice Konstantyna. Egeria opowiada (Itinerarium 37, 1-2), że w Wielki Piątek oddawano hołd relikwiom Krzyża, a święto dedykacji kościoła na Golgocie obchodzono w dniu odnalezienia Krzyża, 14 września (tamże, 48, 1: „,encenia cum summo honore celebrantur, quoniam Crux Domini inventa est ipsa die").

${ }^{40}$ W rękopisie londyńskim (14.644) Maryja jest nazwana wprost „matką Boga” (jaladta 'alaha), czyli Theotokos, zgodnie z nauką chrystologiczną Soboru Efeskiego (431). 